\title{
NEPHRITIS IN CHILDHOOD
}

\author{
BY \\ NORMAN B. CAPON, M.D., M R.C.P. \\ (From The Royal Liverpool Children's Huspitil, \\ for the Medical Resenrch Counci!.)
}

The investigations upon which this paper is based were undertaken primarily to examine the practical value of the so-called " renal efficiency tests " in children. Cases of hidney disease admitted to one of the medical wards of the Royal Liverpool Children's Hospital were systematically cxamined, and the results have been analysed. This has necessitated a general survey of kidney diseases, and of the special peculiarities of these diseases in children. So far as possible, the pathological and clinical aspects have been correlated in the classification adopted; and an attempt has been made to emphasise the necessity of taking a broad general view of each case studied.

The paper is sub-divided under the following headings:-

1. Classification of nephropathies.

2. Methods of investigation.

3. Description of cases studied.

(A) Acute glomerulo-nephritis.

(B) Chronic glomerulo-nephritis.

(C) Diffuse tubular nephritis.

4. Pathological findings in diffuse tubular nephritis.

5. Treatment.

6. Summary and conclusions.

7. Bibliographical references.

\section{Ciassification of Nephropathies.}

It must be admitted that there is at the present time no satisfactory classification of kidney diseases. Of the many schemes which have been suggested (Heubner(12), Newburgh(27), Schwartz and Kohn(28), and Tripputi(31), etc.), one of the best-known is that of Volhard and Fahr( ${ }^{(32)}$, which is here reproduced in abridged form (Table A). This classification has a patholog:cal

TABLE A.

Ciassification 1.

(Modified from Volhard and Fahr.)

A. Nephrosis. Müller, 1905. (No increase of T.P.)

B. Nephritis.

1. Diffuse glomerulo-nephritis. (Increase of B.P.)

2. Focal nephritis. (No increase of B.P.)

C. Renal Sclerosis. 
rather than a clinical foundation, and it marshals cases of kidney disease under three main heads-degenerative, inflammatory and sclerotic; or, in other words, nephrosis, nephritis, and renal sclerosis.

(A) Nephrosis is comparatively a rare condition in which the cells lining the kidney tubules show degenerative changes, without any evidence of inflammation elsewhere in the kidney (e.g., glomerular changes). The various types of degeneration which may be found are stated by Munk(25) to be as follows:-Cloudy swelling or albuminous, fatty, lipoid (cf. myelin kidney of $\mathrm{McNee}(19)$, necrotic, hyaline, amyloid, and possibly glycogendegeneration in diabetes rrellitus.

Poisoning with heavy metals and intestinal intoxication may be mentioned as possible causes of nephrosis.

The studies of Epstein(9) and of Major and Helwig(20) seem to show that cther characteristic features of nephrosis include hypercholesterinæmia, a low metabolic rate and a great increase of serum-albumin as compared with serum-globulin.

(B) Nephritis is comparatively a common disease in which the kidneys show signs of inflammatory response; for instance, hyperæmia and swelling of the tufts, outpouring of exudate and of cells into the capsules of Bowman, leveocytic and lymphocytic infiltration of the interstitial tissue, and degenerative changes in the cells lining the kidney tubules.

(c) Renal sclerosis is a common lesion in adults, but is very rare in children. I shall not consider it in this paper.

Clinically, one of the most important features of nephrosis is extensive and persistent œdema; whereas in nephritis, œdema is variable in degree and frequently is not a prominent feature.

Volhard and Fahr( ${ }^{(32)}$ divided their nephritic cases into two groups, diffuse glomerulo-nephritis and focal nephritis, the difference between them being mainly clinical and concerning the blood pressure. They recognised, furthermore, that focal nephritis may be (1) glomerular, for instance in endocarditis, especially if due to the streptococeus viridans; (2) embolic; or (3) of the septic or acute interstitial type (Councilman), seen occasionally in diphtheria and also after scarlet fever where the throat infection has been very severe.

If the distinction which differentiates "nephrosis" from the betterknown and older term "parenchymatous or tubular nephritis" is not properly appreciated, the modified classification of Volhard and Fahr appears to be no advance upon the former terminology. A certain laxity in adhering to the terms of definition, together with the clinical fact that examples of "parenchymatous or tubular nephritis" frequently bear a close resemblanee to cases of nephrosis, has led several writers to describe as "nephrosis" cases in which there was evidence of inflammation of the kidneys. My own investigutions, though comparatively few in number, demonstrate the applicability to childhood of Volhard and Fahr's statement that nephrosis is a rare condition; and in order prcperly to reco:d the pathological lesion 
which exists in a majority of " large white children," I have suggested a classification (Table B) which is in essence a reversion to the older scheme, but provides also a place for examples of true nephrosis.

\section{TABLE B.}

Classification 2.

A. Nephrosis. (Some cases of parenchymatous nephritis.)

B. Nephritis.

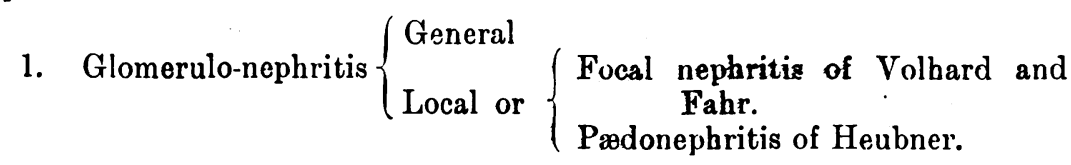

2. Diffuse tubular nephritis. (Most cases of parenchymatous or

3. Focal nephritis. tubular nephritis.)

(a) Acute interstitial nephritis.

(b) Acute and subacute embolic nephritis.

C. Renal Sclerosis.

It is a truism to state that when a child's kidneys become inflamed, it is rare to find on histological examination that any one of the component structures of the kidney has escaped: there are few examples of nephritis which do not show diffuse nephritis.

I have employed the word "diffuse" to emphasise one special and important feature found in the kidneys of " large white children," namely. the very widespread extent of the lesion. At the same time, the clinical and pathological advantages gained by emphasising in our terminology which particular component of the kidney has been mainly affected have not been forgotten.

The difference between what I have called general and local glomerulonephritis is only a question of degree, namely, the number of glomeruli affected. It is said that successive reports on the state of the cardiovascular system provide a measure of this factor. Upon this topic, which is, I think, relatively of small importance, a voluminous literature must be consulted; I have summarised it by accepting the view that Heubner's(13) pædonephritis is the same condition as Volhard and Fahr's focal glomerulo-nephritis.

\section{Methods of Investigation.}

Reference to Table $\mathrm{C}$ will give at a glance the general scheme of investigation followed, though it will be obvious that for certain cases it was necessary, on medical grounds, to exercise discretion in the application of tests. Furthermore, it is well recognised that difficulties encountered during the investigation of renal cases are more frequent and more insurmountable 
in children than in adults. For instance: (1) urine collection without catheterisation may be impossible; and the total volume in 24 hours is often inaccurately recorded even in older children; (2) blood vessels are small and one may have difficulty in obtaining blood for examination: in some cases I used the patient's saliva for the estimation of urea; (3) emotional disturbances are frequent in children; therefore blood pressure records are often not reliable; (4) accurate dieting is a great difficulty; one cannot expect the co-operation from a child which one receives from an adult.

For these reasons, tests were sometimes unsatisfactory; and sometimes the delay between repetitions of the same test was longer than one would have wished.

TABILE C.

\section{$\therefore: \cdots \quad$ Plan of Investigation.}

1. Medical history of patient and of relatives.

2. General clinical examination, with special reference to

Body-weight.

Edema.

Anæmia.

Heart and blood vessels. B.P.

Optic fundi.

Septic foci, e.g., teeth and tonsils.

3. Urine. Daily Examination.

(a) General. Volume: sp. gr.: reaction.

(b) Chemical. Protein content.

Urea content.

Chloride content.

(c) Microscopical.

4. Blood. Nonprotein nitrogen.

Wassermann reaction.

5. Renal efficiency tests.

(a) Phenolsulphonephthalein excretion.

(b) Urea concentration test.

(c) Salt test.

(d) Fixation of specific gravity test.

6. “Living kidney" examination.

7. Autopsy. Histology. 
The following notes are supplied in amplification of the scheme shown in Table C:-

Urine. For some time.I estimated the diastase content of urines daily, but later discarded this test. 'The chloride content was estimated by Harvey's modification of Volhard's method (see Myers (26)).

Blood. Non-protein nitrogen was estimated by a modified Kjeldahl process, with subsequent nesslerisation and colorimetric comparison.

Renal Efficiency Tests. From the outset one kept in mind the limitations which workers on adults have shown to exist in the use of these tests, as well as the caution which must be exercised in making deductions from the results obtained. For instance, it is not yet accurately known which particular functional capacity of the kidney is tested by the different functional tests. Furthermore, it must be remembered that in health no single activity of the kidney is exerted to the full: the organ possesses what may be described as a big "reserve power" and frequently no evidence of functional incapacity is revealed until damage is widespread and severe. In other words, the kidney conceals its own weaknesses at a time when the physician wishes to discover them; and when the lesions are no longer small enough to be hidden, obvious clinical signs frequently appear.

Another difficulty lies in the fact that the functional efficiency of kidney tissue which has developed by compensatory hypertrophy is unknown. Moreover, the functions of the kidney are disturbed by most severe diseases of the viscera, especially of the heart, blood vessels, lungs and blood; as also by all so-called "general diseases," for instance, fevers. Hence impairment of function, as shown by efficiency tests, may be only the shadow and not the substance. Wilcox and Lyttle(33) and Gittings and Græme Mitchell(11) give interesting figures in relationship to this aspect.

In healthy children the two-hour excretion of phenolsulphonephthalein, administered intramuscularly, should be at least $60 \%$. I. W. Hill(14) found it to be $76 \%$, Leopold and Bernhard(16) $70 \%$, Curtis ${ }^{(6)} 75 \%$, Tileston and Comfort(30) $89 \%$, and Wilcox and Lyttle(33) $60 \%$. When oedema is present, the test by intramuscular route is almost valueless; and when there is blood in the urine the estimation of the excreted dye is generally impossible. On several occasions I found the matching of colours in measuring the excreted 'phthalein a very difficult matter even when there was no blood in the urine; the addition of alkali to bring out the colour of the dye precipitates phusphates, which interfere with the colour comparison. The phosphates may be separated, but this renders the test less accurate. The urea concentration test was carried out according to the method described by McLean(18), except that the dose of urea employed was 10 grams. By the term " salt test" I refer to the exhibition of 10 grams of sodiurn chloride, with subsequent investigation of increase of weight, due to œdema, and of the urinary excretion of salt. This test undoubtedly aggravates the patient's condition temporarily; it was used on a few occasions only. 
The fixation of specific gravity test was found to be applicable only to the older children; I have little experience of it.

"Living Kidney" Examination. In certain cases, decapsulation of the kidneys was performed, and I am greatly indebted to Mr. R. C. Dun, Senior Surgeon to the Roval Liverpool Children's Hospital, for his kindness in assisting me by excising a small wedge of kidney substance during the operation. This piece of tissue was dropped at once into formalin and was later examined microscopically. By this method of examination a fuller knowledge of the kidney lesion is gained.

\section{Description of Cases Studied.}

During the past three years I have had the opportunity of observing some 20 cases of nephropathy in children between the ages of $2 \frac{1}{2}$ and 12 years. One of these cases has been published under the names of Dr. Dingwall Fordyce and myself(10) and I shall not include it in this paper.

Four other cases could not, for various reasons, be studied adequately, and I have excluded them from this survey.

Of the remaining 15 cases I have classified three as acute glomerulcnephritis, six as chronic glomerulo-nephritis, and six as diffuse tubular nephritis.

\section{A. Acute Glomerulo-Nephritis.}

Only brief reference will be made to these three cases.

M. D. Female, age $3 \frac{1}{4}$ years. For some weeks before the onset of nephritis this child had been debilitated; there had also been otorrhœa and a vaginal discharge. An eruption resembiing "points of blood" was noticed on the body and legs two weeks before the child was brought to hospital suffering with pyrexia, oliguria, hæmaturia and proteinuria-(7 gms. per litre). There was a moderate grade of odema of the subcutaneous tissues; and numerous impetiginous areas were scattered widely on the skin. Microscopical examination of the urine showed numerous casts of all descriptions 'The extreme gravity of the patient's condition made systematic examination impossible. 'The systolic blood pressure was about $90 \mathrm{~mm}$. of mercury; possibly this is too high an estimate because the child was in an irritable, frightened state. She died a few days after admission and an autopsy was refused. There does not appear to be sufficient evidence to say that nephritis was secondary to impetigo, though this is probable.

D. S. Male, age $2 \frac{1}{2}$ years. Oliguria and hæmaturia developed immediately after pneumonia. The urine contained 2 to $3 \mathrm{gms}$. of protein per litre and numerous casts were found. The temperature on admission was $103^{\circ}$, but it fell to normal almost at once and recovery was rapid. When the patient was re-examined 12 months after his attack, his general health was quite satisfactory, the urine was normal and the systolic blood pressure was $112 \mathrm{~mm}$. of mercury. This is a high figure for a child of $3 \frac{1}{2}$. years.

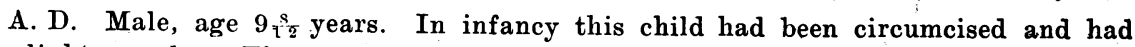
had slight measles. There was no illness preceding the attack of nephritis, except a "cold in the head." 'The onset was characterised by rise of temperature, vomiting, and $r$ ain in the right side of the abdomen : these signs, together with anorexia and very slight jaundice suggest that a catarrhal cholangitis had developed. Proteinuria, up to $1 \mathrm{gm}$. per litre, was discovered: erythrccytes and leucocytes were present in the urine, but no casts were found. Slight odema of the ankles was noted. The blood non- 


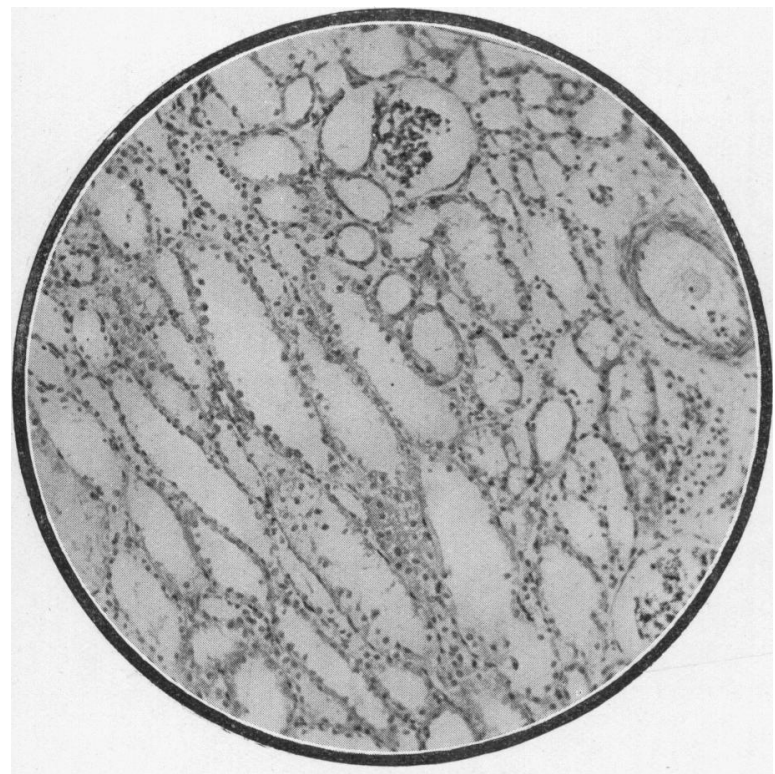

Fig. 1.

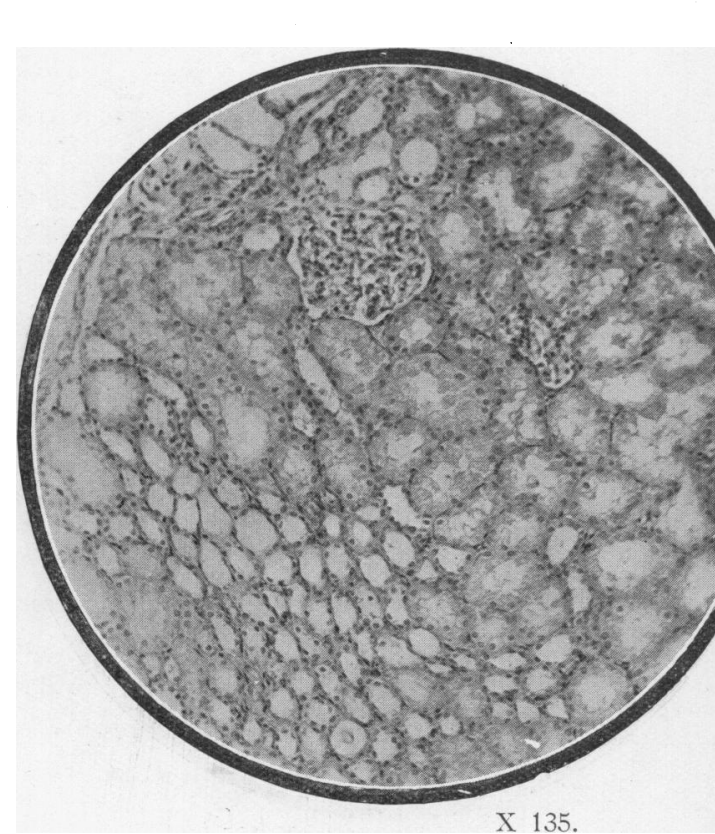

Fig. 2.

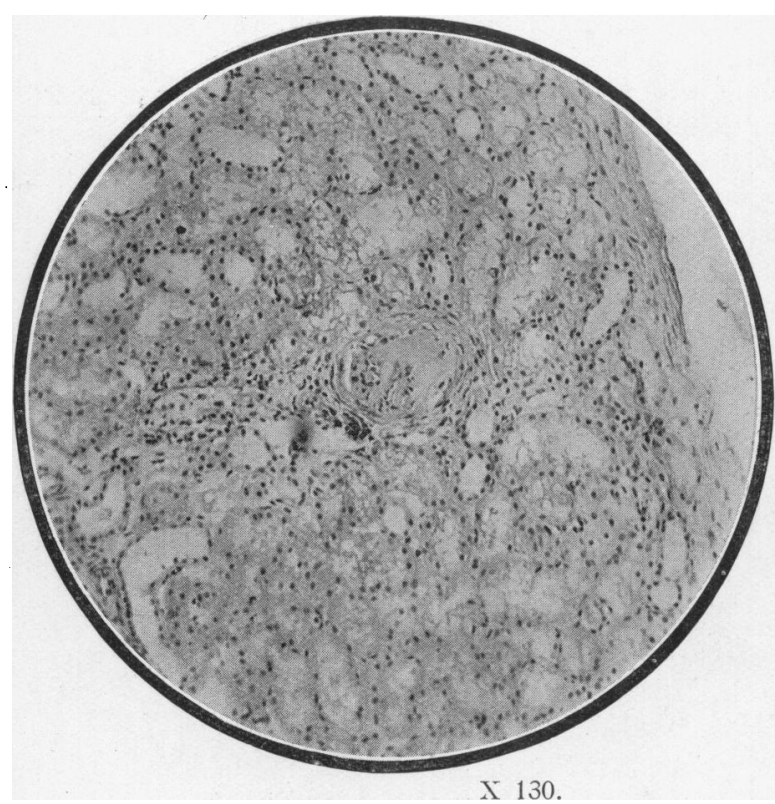

Fig. 3.

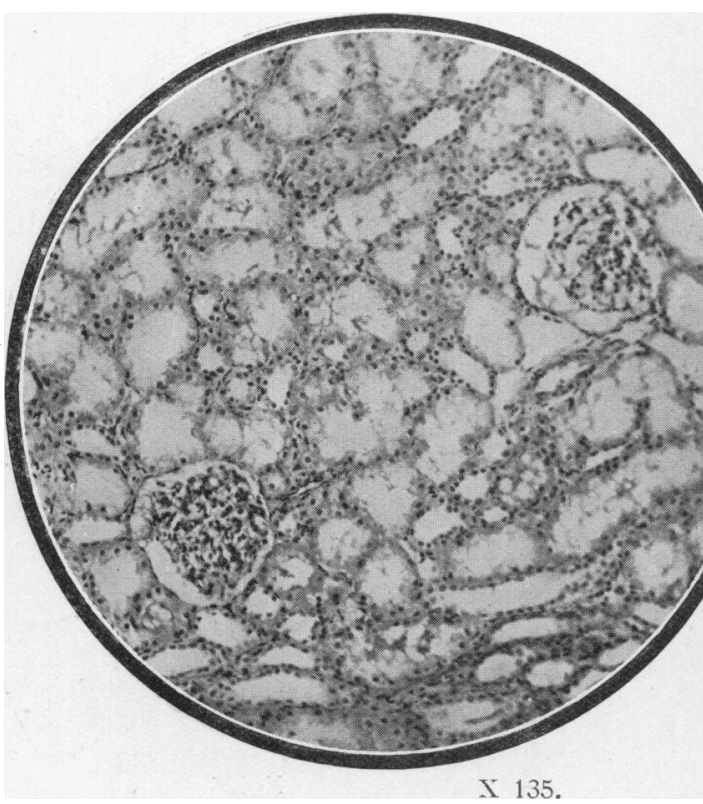

Fig. 4.
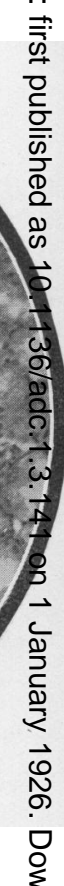

잉 


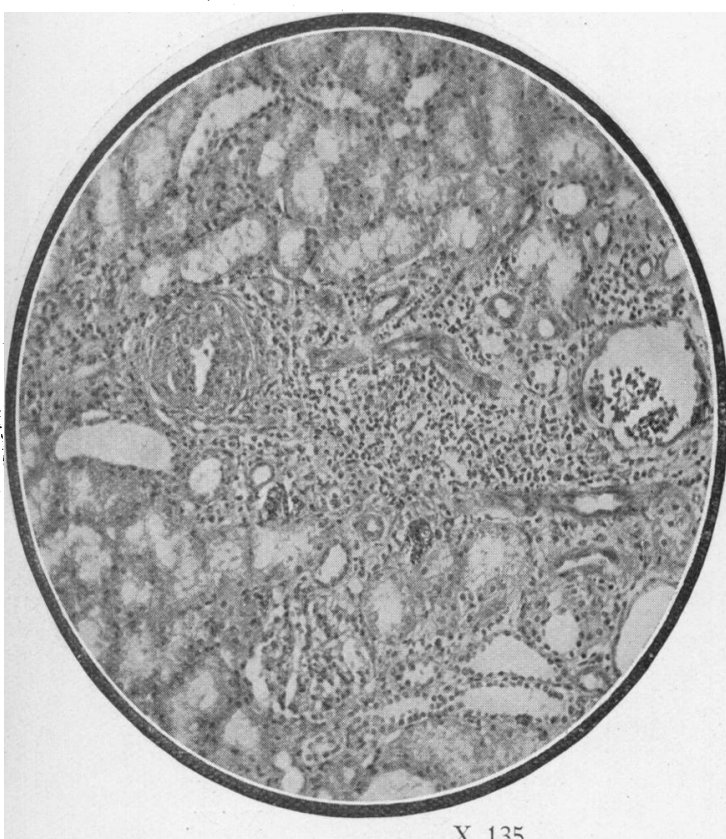

Fig. 5.

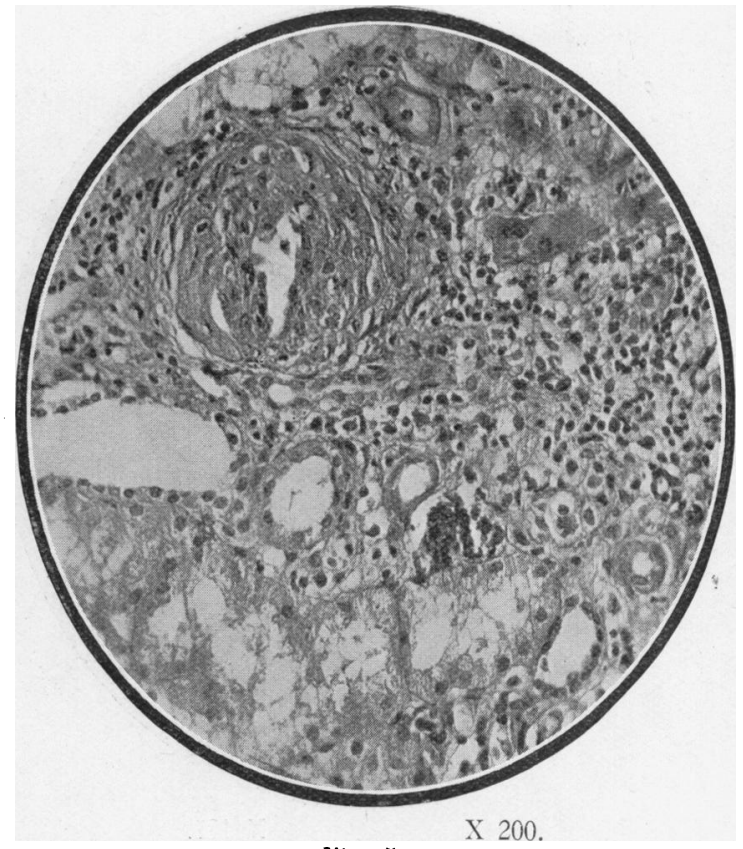

Fig. 5a.

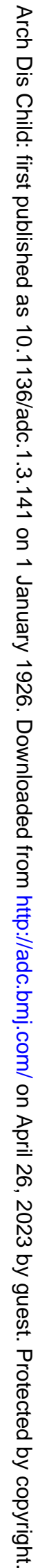

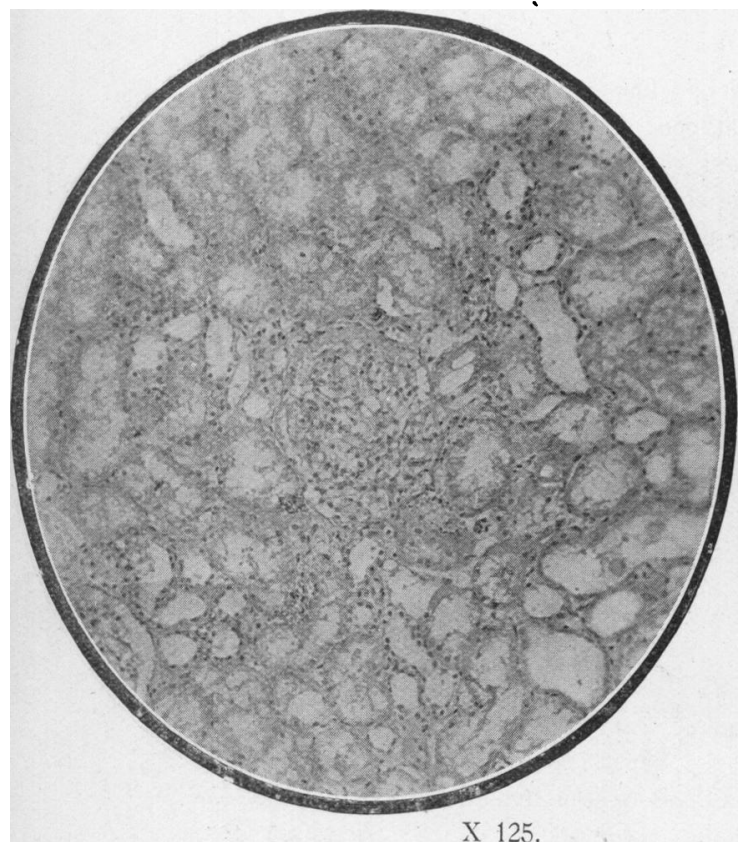

Fig. 6.

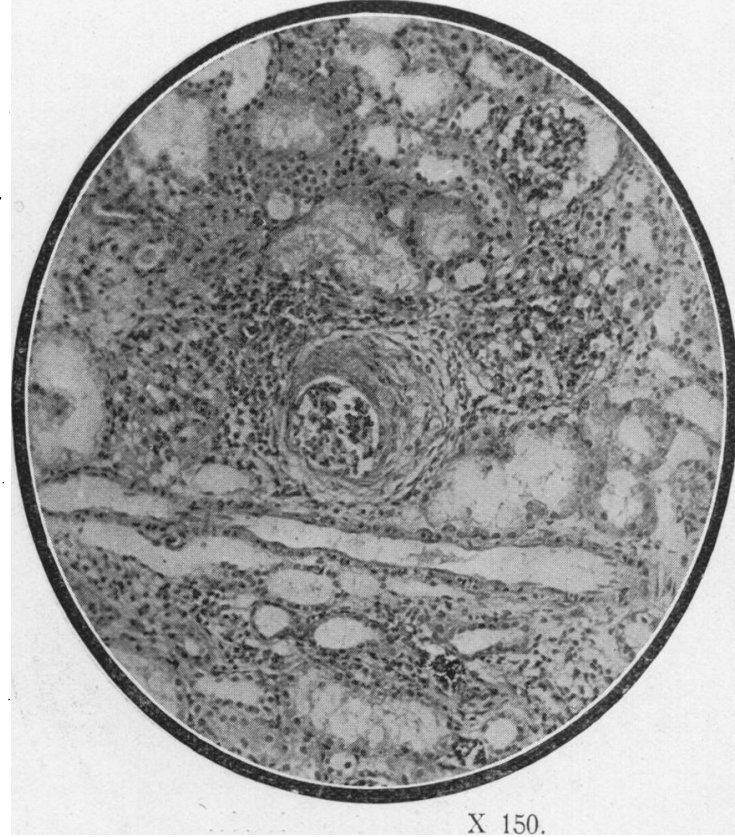

Fig. 7.
X 150 . 
protein nitrogen was $37 \mathrm{mgs}$. per 100 c.cms. of whole blood, and the two-hour 'phthalein excretion was $94 \%$. Recovery was rapid; and when the patient was re-examined $11^{7}$. years after this attack he was found to be in normal health, and his urine was normal. The systolic blood pressure was $117 \mathrm{~mm}$. of mercury (age of patient $11 \frac{1}{4}$ years).

\section{B. Chronic Glomerulo-Nephritis.}

This form of nephritis affects especially children of school age. The conset may be sudden, with an acute nephritis, or it may be gradual. In either case the disease is frequently preceded by one of the exanthemata, or by some infective condition, for instance, tonsillitis, to which special attention has been drawn by many observers, including Cautley(3), Marriott(21), Allison(1), and D. Is. Smith and C. W. Bailey(29).

When the onset is insidious, anorexia, headache, vomiting, oliguria and hematuria are frequent symptoms; œdema is variable in degree, but is generally not a prominent sign except during an acute exacerbation. Pallor and general malnutrition are almost always found. Some cases bear a striking resemblance to tuberculosis of the kidneys and urinary tract.

'I'he following are abbreviated records of my cases; additional notes will be found in Table D:-

M. S. The patient had whooping-cough, chicken-pox, measles with pneumonia, and severe scarlet fever, all during one year. Bilateral otorrhœa developed as a complication of scarlet fever, and the mother noticed that the urine was becoming scanty and dark coloured. Headaches, anorexia, general malaise and some odema of the face, body and legs were additional complaints. The parents noted that the symptoms showed cyclical exacerbations, each attack lasting about two weeks. Edema soon disappeared and has not redeveloped at any time. She is a thin, frail, nervous child; her teeth and tonsils are not above suspicion.

G. R. Parents are Russian Jews; healthy. The patient had whooping-cough, chicken-pox, measles and mumps in early childhood. Adenoids removed at 3 years.

No illness immediately preceded the present complaint, which began with cough, anorexia and vomiting; also slight pains in the chest and abdomen on exertion. There was some headache, fever and sweating. The urine was noticed to be dark coloured. Shortly after the onset, right-sided pleurisy with effusion developed. The fluid was straw coloured and contained large numbers of small lymphocytes; neither tubercle halli nor other micro-organisms were discovered and cultures were sterile. Later, radiographs of the cliest showed no evidence of tuberculosis. Von Pirquet reaction regative. Radiographic examination of kidney regions was negative. No tubercie bacilli were found in the urine or fæces; guinea-pig inoculation with urine was negative for tubercle bacilli.

The patient is a well-developed, fat boy with slight odema below the knees. Teeth and tonsils healthy.

W. C. The patient had whooping-cough in infancy, hæmorrhagic measles when $6 \frac{1}{2}$ years old and chicken-pox when $7 \frac{1}{2}$ years old. He is stated to have bled freely after circumcision and after extraction of teeth. With the onset of tracheitis when $8_{1}^{+}$years old, the parents noticed that the urine was dark coloured; there was also some loss of appetite. Whenever he caught a " chest cold," which was a frequent occurrence, the urine became bright red, with increased frequency of micturition during the day, and there was anorexia and increased pallor.

Between these attacks the urine did not become nornal in colour. He is a thin, frail, alert child of unusually high intelligence. No sdema has been noted. On 
admission to hospital he was found to have calcareous lymphatic glands in the abdomen; these were confirmed by radiograph. There were no signs, clinical or radiographic, of tuberculosis elsewhere. Examination of the bladder by radiography and cystoscopy, and of the urine by microscopy and by guinea-pig inoculation, were all negative for tuberculosis. 'The teeth were satisfactory; tonsillectomy was required and was carried out in June, 1924.

E. D. The patient had not suffered with any previous illnesses except enuresis. The onset occurred with a "bilious attack," followed by puffiness around the eyes, and possibly by a purpuric eruption on the Iegs. 'The patient was a thin, pale, nervous girl, with spasmodic internal strabismus. There was no œdema. The teeth were satisfactory; but the tonsils were found to be unhealthy and were removed in December, 1923. Blood coagulation time and fragility tests were normal. No tubercle bacilli were found in the urine.

R. T. Fairly healthy family history. There was no known cause for the onset of hæmaturia in this patient; it began fre weeks before admission to hospital and continued intermittently. Von Pirquet reaction was negative. Radiograph of the chest showed a good deal of spottiness of and adjacent to the right lung root. Radiographs of the kidney regions showed nothing abnormal.

C. R. The patient's previous illnesses were measles, one year before the present trouble, and frequent attacks of nocturnal enuresis. The complaint began with putfiness of the face which was noticed after an attack of scarlet fever; at the same time the urine was noticed to be dark red in colour. The appetite was greater than usual. The patient was found to be a fairly well-nourished, pale child, with slight ordema of the shins. Four very septic teeth were extracted and tonsillectomy was performed in May, 1924.

In the urine of these patients red blood corpuscles and leucocytes, hyaline, granular and epithelial casts were almost constantly present. Blood casts were less frequently seen. Epithelial cells, probably from the kidney tubules, were commonly found. It should be noted that the amount of protein passed in the urine in chronic glomerulo-nephritis is comparatively small. The optic fundi were normal in all cases. The cardiac dulness was normal in extent in all patients except G. R., in whom it was possibly increased ( $3 \frac{1}{2}$ inches from the mid-sternal line in the fifth intercostal space: age of patient at this time was 13 years). No case showed signs of organic heart disease.

It will be seen on reference to Table D that abnormally high blood pressure readings were observed in each child except $R$. T., in whom records were not made; but it must be pointed out that by the time G. R.'s systolic blood pressure was $180 \mathrm{~mm}$. of mercury (age of patient $=13 \frac{1}{4}$ years), his urine had become normal; and similarly when E. D.'s systolic blood pressure was $134 \mathrm{~mm}$. of mercury (age of patient $=11 \frac{7}{12}$ years), her urine was normal.

In attempting to determine the prognosis in cases of chronic glomerulonephritis it is important to remember that two processes, one progressive and the other regenerative, are probably taking place. The former includes epithelial inflammation, recognised by finding protein in the urine, and kidney sclerosis. So long as proteinuria continues one may assume that progressive inflammatory changes are taking place; improvement may be recorded when proteinuria is diminishing or has disappeared. Any 


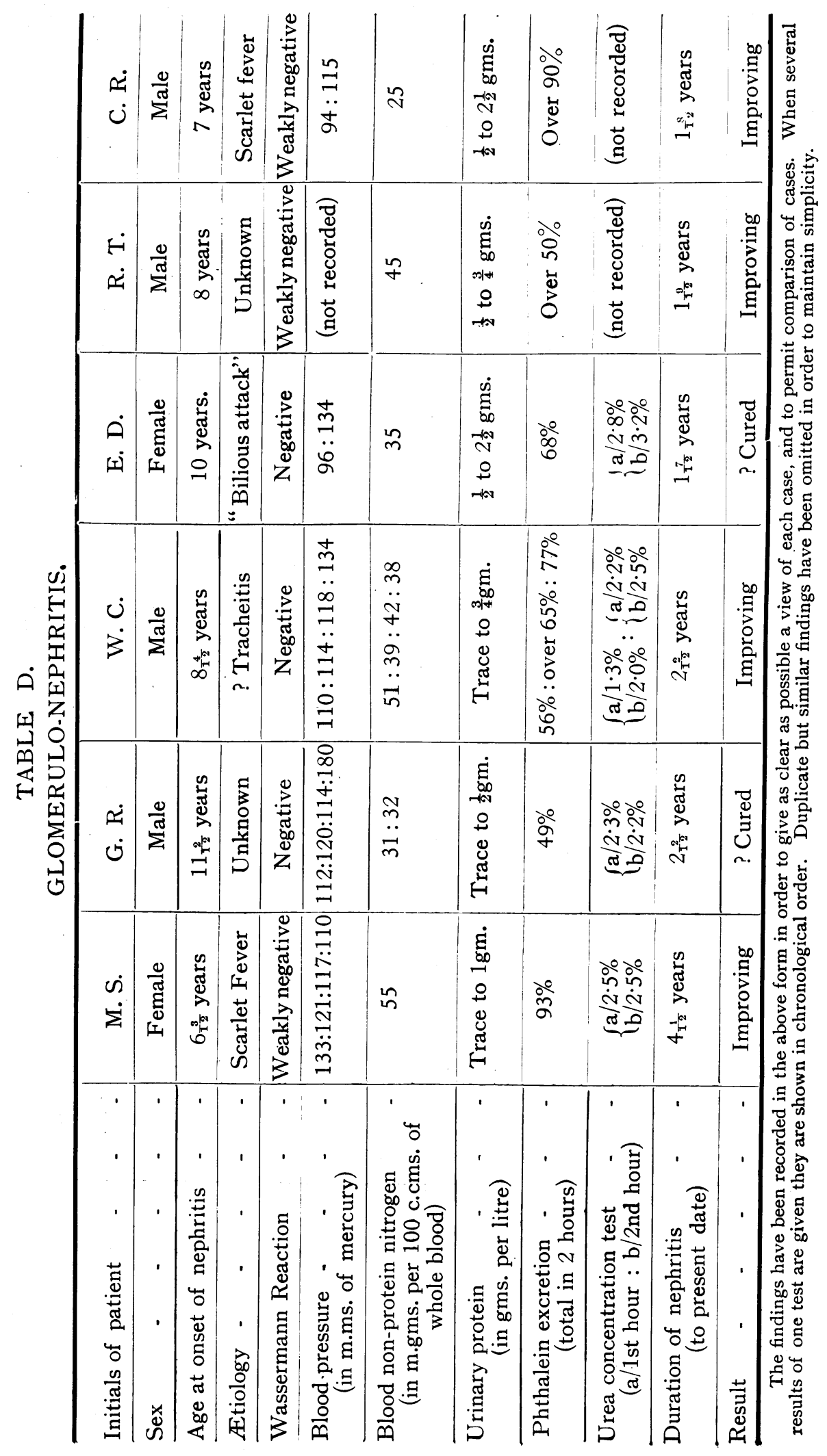

궁

$\frac{0}{\omega}$

을

产

$\frac{\sqrt{2}}{\frac{0}{5}}$

๗

$\vec{\circ}$

$\vec{\omega}$

\%ั

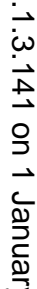

용

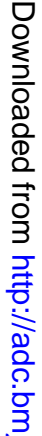

产

잉

공.

N

స్ల్ట

У

$\stackrel{\circ}{\Phi}$

뭉

윰

$\stackrel{\circ}{\circ}$

श

윰 


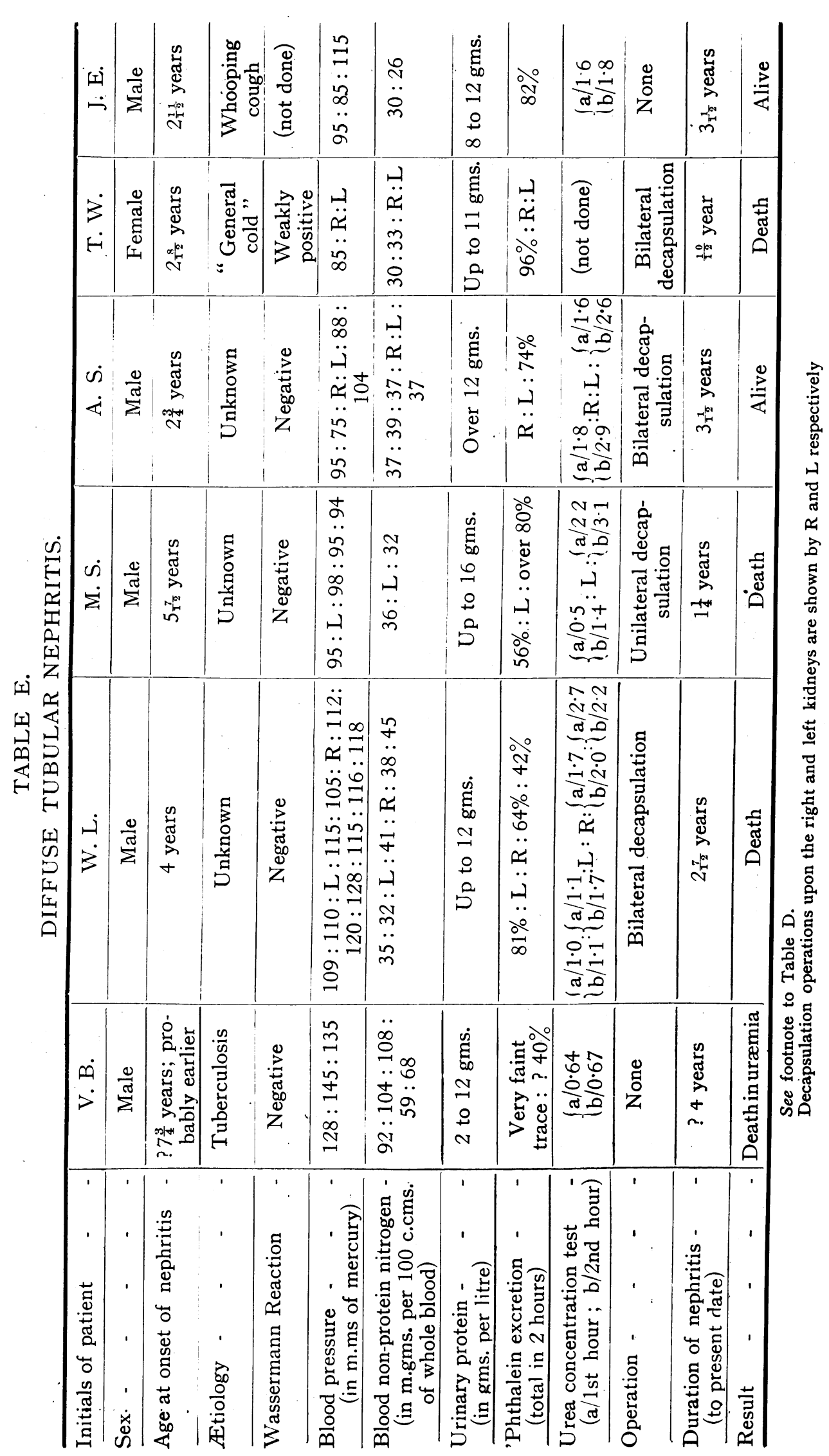

궁

$\frac{\square}{\omega}$.

음

$\overrightarrow{\vec{p}}$

ㅁ

$\frac{\bar{v}}{\bar{a}}$

क

o

$\overrightarrow{\vec{\omega}}$

응

के

$\pm$

9

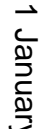

芯

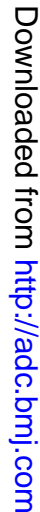

웅

을.

กั

옹

एँ

通

뭉

융

윰

פ

융 
effect which kidney sclerosis may have upon the cardiovascular system seems to depend upon the distribution and stage of the lesion; hence the blood pressure may or may not be raised in chronic glomerulo-nephritis. When it is permanently elevated serious kidney disease is present.

Regeneration of kidney tissue plays a greater part in the ehild than in the adult, and its effect in concealing the true extent of the pathological change is probably greater the younger the patient. In the two patients G. R.* and E.D. it is evident that at the time of the last urinary examination there was no active kidney inflammation; but the histories of the cases, together with the blood pressure records, furnished proof sufficient to classify them as chronic glomerulo-nephritis. If they had been examples of local glomeruło-nephritis, altematively termed Volhard and Fahr's focal nephritis and Heubner's pædonephritis, the blood pressure would not have been higher than normal [Heubner(13), Tripputi(31) and others]. Mendel(23) has pointed out that since the time when Heubner gave his original description of pædonephritis it has been shown that this syndrome has not the clear cut boundaries which it was at first believed to possess. I submit that if the term pædonephritis is to be retained it must be regarded as a mild form of chronic glomerulo-nephritis, and not as a separate entity. There are obvious disadvantages in introducing new words to differentiate cases which seem to vary only in the extent of the lesion.

The possibility of a recurrence of acute nephritis in these cases is considerable; and Emerson ${ }^{(8)}$ has emphasised that even minor symptoms mav be of grave significance, because they furnish evidence of advancing epithelial disease. Hence it is most difficult to say when a case of chronic glomerulo-nephritis is cured. Even if there has been no active inflammation for several years, it is possible that delayed vascular complications may appear in adult life.

\section{Diffuse Tubular Nephritis.}

The most striking feature of this form of nephritis is severe generalised wedena. The age of the patient is usually younger than in chronic glomerulonephritis. Cold and exposure have always been regarded as ætiological factors; at times tuberculosis, syphilis and chronic suppurative conditions are antecedents. Marriott(21) finds that staphylococcal infection of the nasal sinuses is often the primary cause. The onset of the disease is generally insidious, with pallor, oliguria and odema. Pyrexia is often only slight; sometimes it is absent. Hæmaturia is seldom noticed. Proteinuria is considerable, and many casts of all descriptions-especially hyaline, granular, epithelial and fatty-are found in the urine. Leucocytes and cells from the renal tract are numerous. Erythrocytes are scanty.

*A few days before the completion of this paper, the patient G. $R$. suffered an acute exacerbation of nephritis, characterised by general malaise, oliguria and hæmaturia, with numerous urinary casts, 
Retention of nitrogen in the blood is infrequent; but the power of chloride elimination is considerably diminished. The blood pressure is not raised and the heart is not hypertrophied. There are no changes in the eye grounds. Death is frequently due to some intercurrent infection.

Attention must be drawn to the fact that the newer conception of this condition makes it a "general metabolic disturbance" rather than a local kidney disorder with secondary œdema.

Linder, Lundsgaard and van Slyke(17) have emphasised the great fall in concentration of plasma proteins found in this disease; and Clausen(4) has noted the lowering of surface tension, both of the blood and of the urine. Furthermore, this observer has shown that the substance which has this effect can increase the permeability of collodion membranes for protein.

At autopsy the kidneys are generally found to be of the large, pale variety, with or without amyloid degeneration. The cortex is wider than normal and is of a light yellow or light red colour; it is clearly differentiated from the medulla. Further reference to the pathology of this condition will be made later.

It is for this form of nephritis that Edebohls'(7) operation of bilateral kilney decapsulation has been most strongly advocated; and there is evidence to show that improvement sometimes follows this procedure, though the actual effect of the operation on the kidneys is not properly understood. Edebohls (loc. cit.) believed that decapsulation allowed new blood vessels to grow from the perinephric tissues into the kidneys. He was aware of the fact that after decapsulation a new capsule develops-in fact he recommended re-decapsulation if the patient's symptoms began to return after temporary improvement; but he held that the new capsule becomes organised in from three weeks to three months, and that it is always more succulent and vascular than the original capsule. Other observers have demonstrated that the new capsule formed after decapsulation is avascular* and that any beneficial effects following the operation must rather be ascribed to the relief of kidney tension. This hypothesis may be appropriate to cases of acute nephritis, but it is unlikely that increase of kidney tension is an important feature of subacute and chronic nephritis. Edebohls reports that he never noticed any evidence of increased renal tension in cases of chronic nephritis.

'These difficulties have been discussed in a review of the subject of decapsulation in "Medical Science" (22) and also by J. Lovett Morse(24). It is probable that renal decapsulation would give better results if performed earlier in the history of the case. The practical difficulty lies in selecting

*There is much truth in the contention of Edebohls that since most of the experimental work on this question was carried out on the kidneys of normal, or acutely nephritic animals, the findings cannot properly be compared with the results in chronic nephritic humạn kidneys. As yet the reports on human cases are very few, 


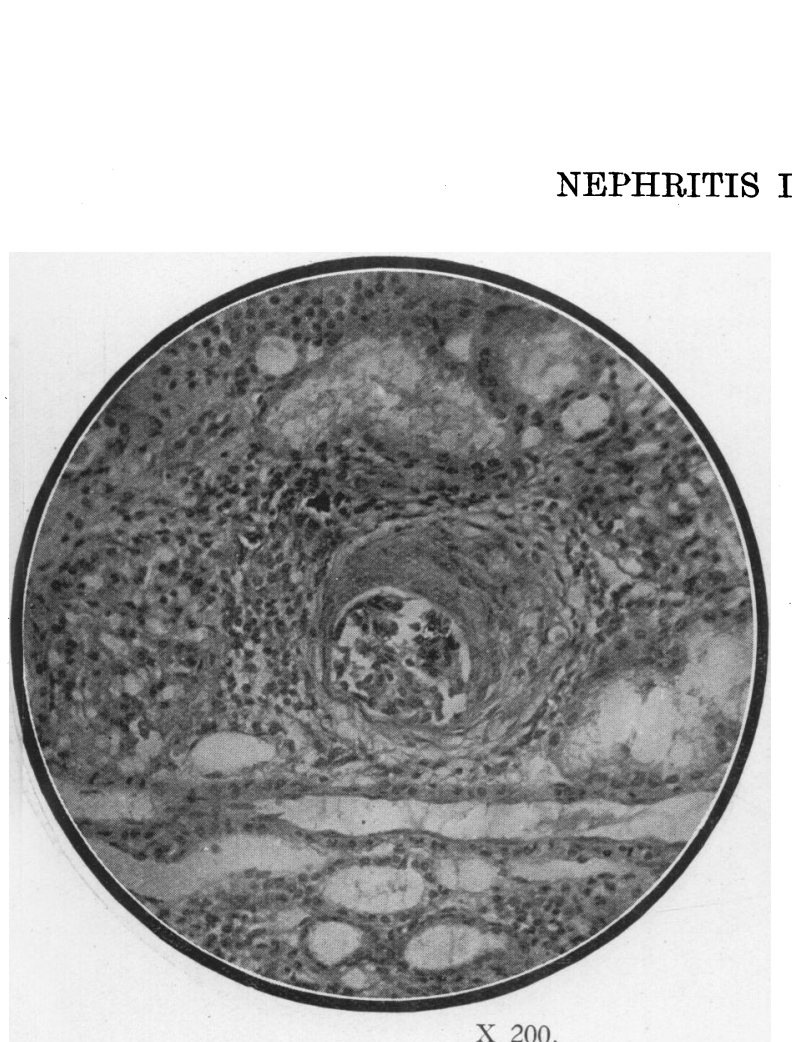

Fig. 7a.

\section{200 .}

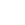

CHILDHOOD

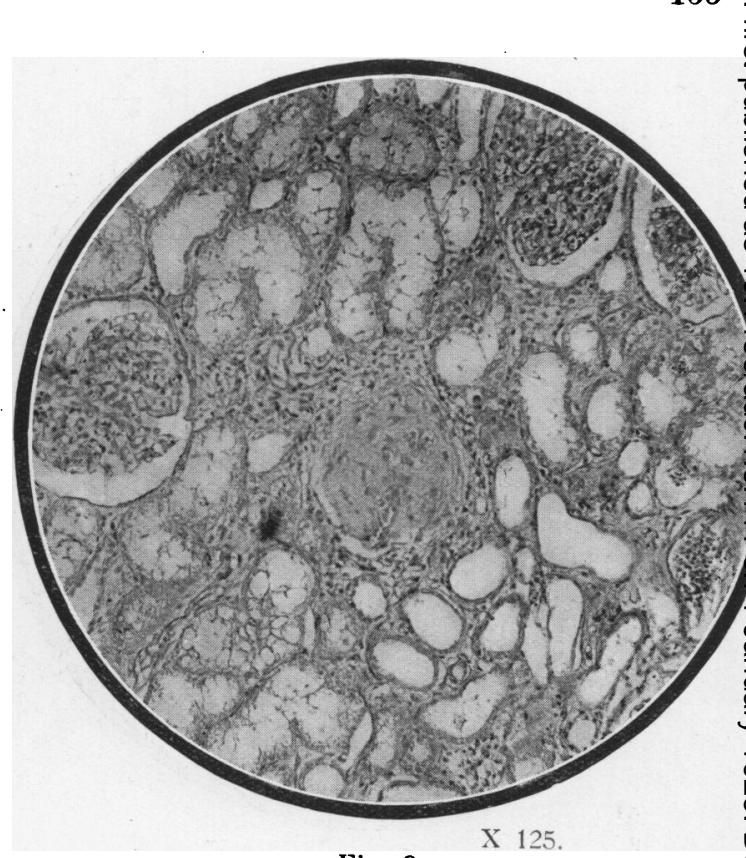

Fig. 8.

X 125 .

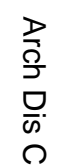

을

寻

흠

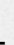

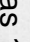

P

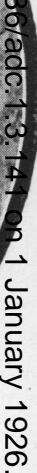

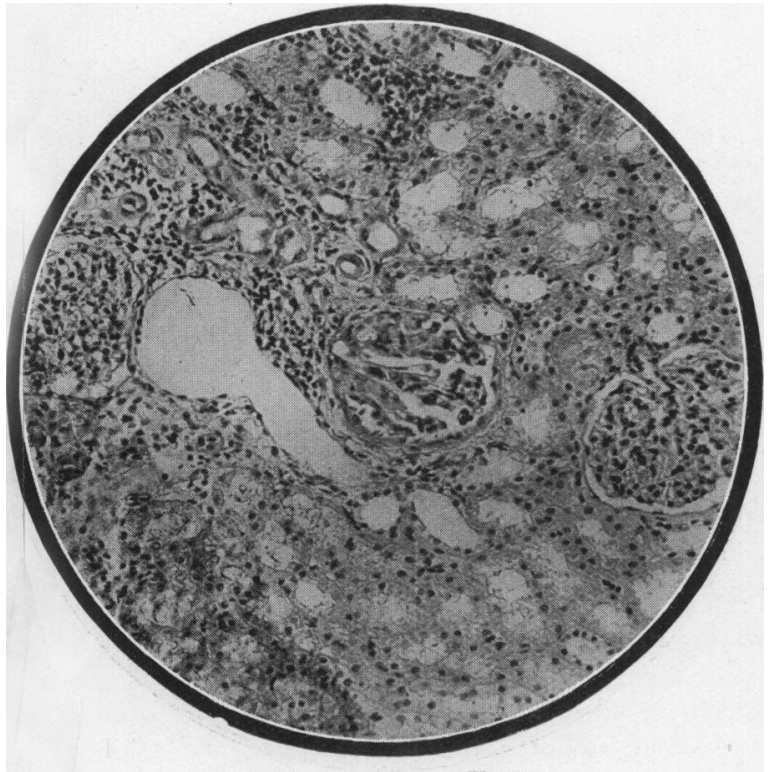

Fig. 9.
X 135.

x

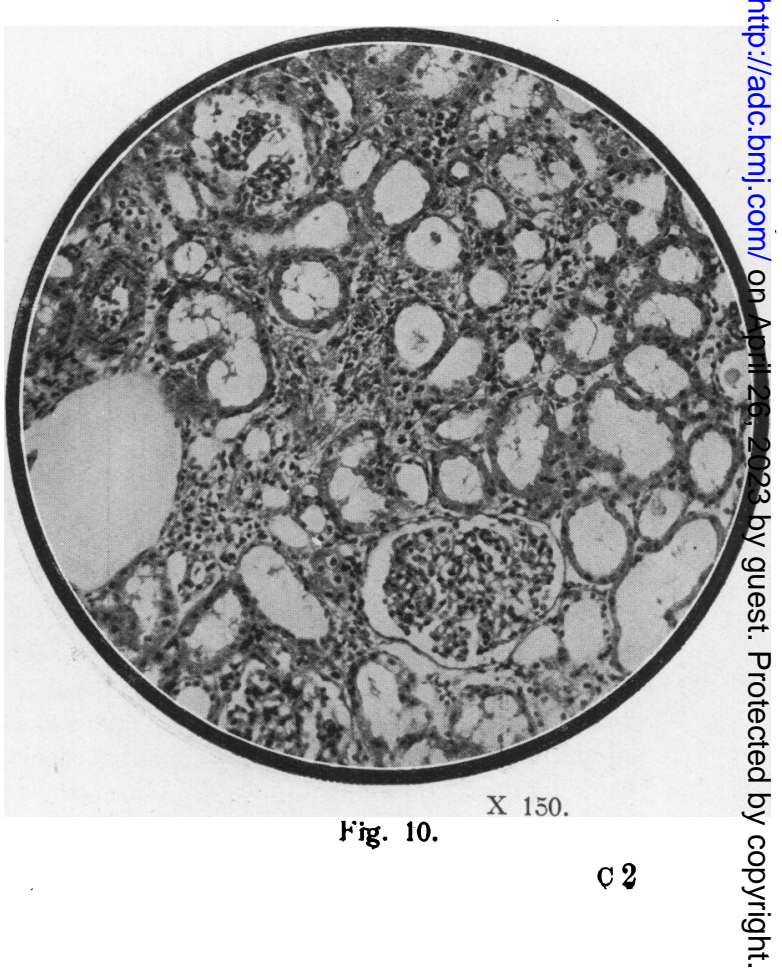




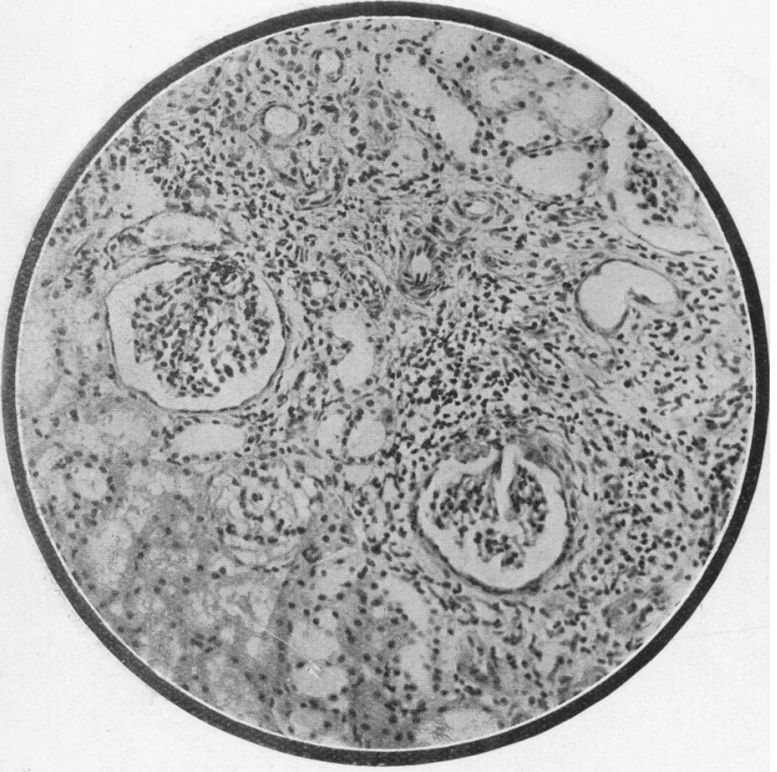

Fig. 11.
X 135 .

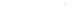

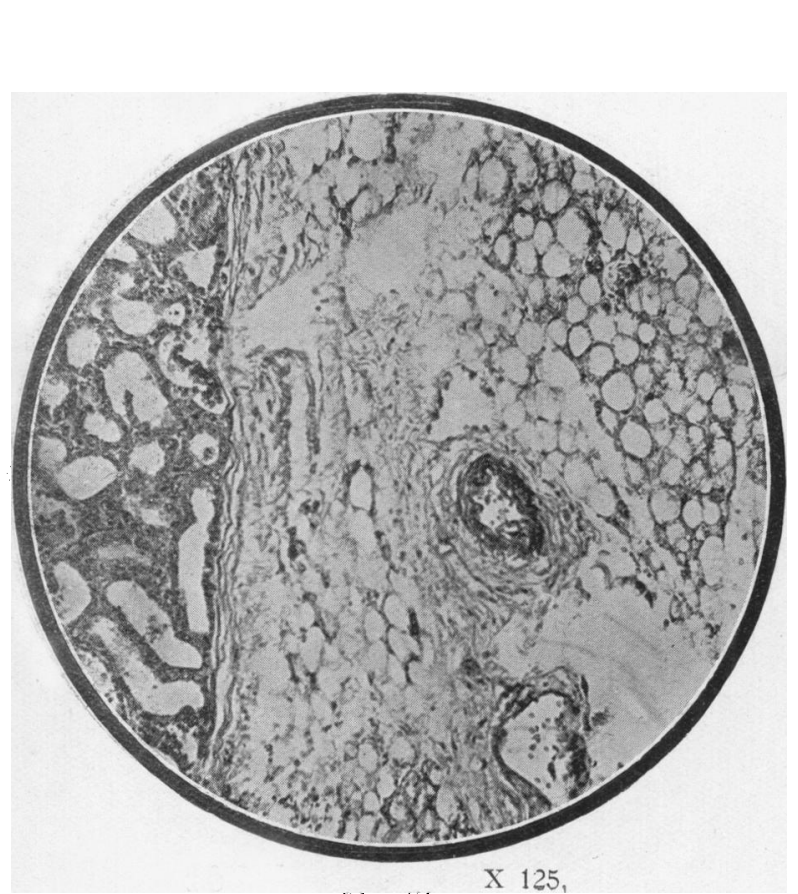

Fig. 13

(H) 13

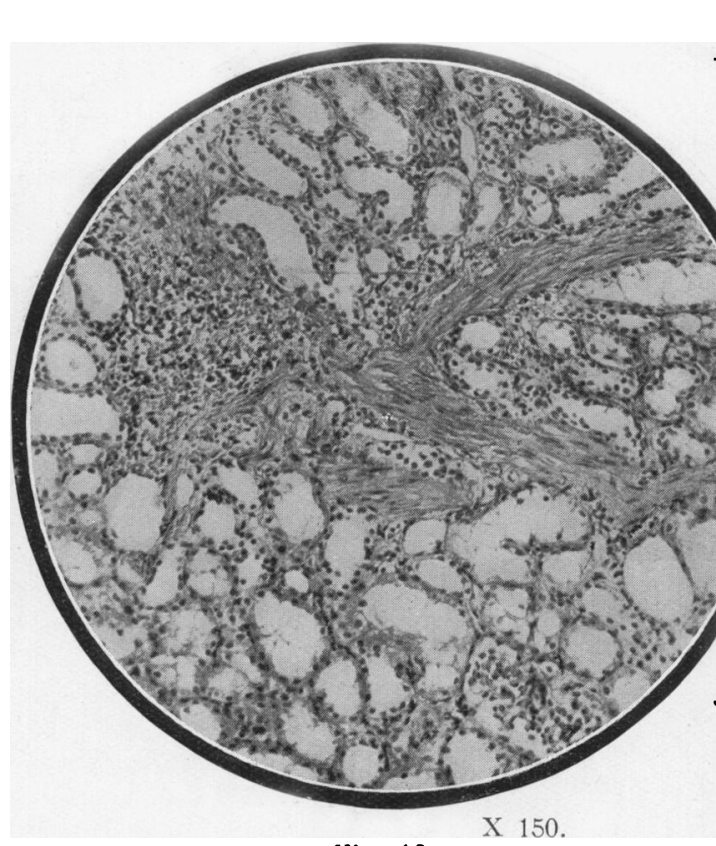

liig. 12.

$$
\text { liig. } 12 \text {. }
$$

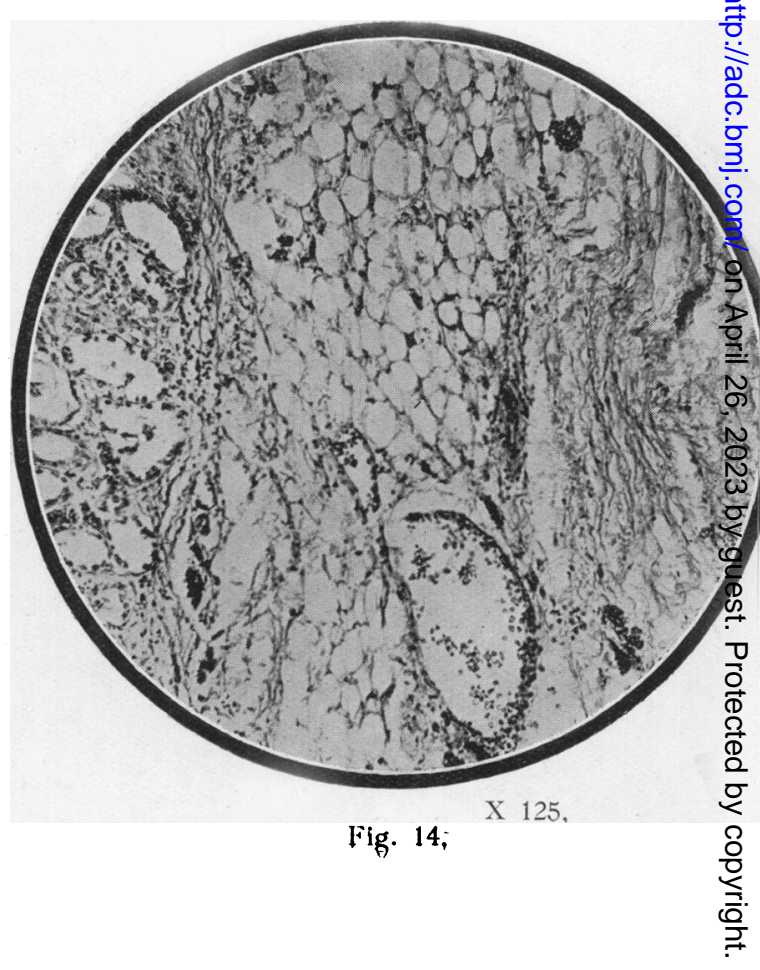


those cases of acute and early subacute nephritis which will not recover under medical treatment alone. Until we are able to do this it is unlikely that renal decapsulation will be extensively employed except as a last resource.

The operations upon the cases here reported were performed by Mr. R. C. Dun, who decapsulates only one lidney at a time and allows about one month to intervene between the two operations. He believes this procedure to be safer than the double operation. Four patients in this series underwent decapsulation; in one case it was unilateral only.

The following are brief notes of my own cases; additional details will be found in Table $\mathrm{E}$ :-

V. B. This boy came under observation at the age of 10 years. His father had died of phthisis when the patient was 11 months old; seven months later a tuberculous alscess dereloped on the right side of the boy's face. At the age of 2 years tuberculous dactylitis was diagnosed. Two months later the left knee joint was similarly affected and discharged through several sinuses. It is certain that the patient's kidneys were diseased by the age of $7 \frac{3}{4}$ years; probably they were affected some considerable time hefore this.

When the child came under my observation he had been odematous for about five weeks; the other chief symptoms were anorexia, lethargy, oliguria, headaches, epistaxis, vomiting and diarrhoea. He was found to be a very pale child, with numerous scars and bone deformities due to former tuberculosis. There were some carious teeth, and the tonsils were enlarged and slightly inflamed. The submaxillary and axillary lymphatic glands on both sides were enlarged. The heart was hypertrophied, the deep cardiac dulness being in the fifth left intercostal space four inches from the midsternal line; the second aortic sound was accentuated. Ascites and slight bilateral hydrothorax were present in addition to generalised subcutaneous odema.

The child improved under treatment (note diminution of non-protein nitrogen of the blood); this suggested that the symptoms were largely due to an acute exacerbation of nephritis in kidneys affected by chronic changes, probably with amyloid degeneration. At a later examination the spleen was found to be palpable.

One week before death (age $11_{\frac{3}{2}}^{\frac{3}{2}}$ years) the patient was re-admitted in uræmia, with severe headaches, oliguria and vomiting as main symptoms. Edema was scarcely noticeable; several uræmic convulsions, with increasing drowsiness, ushered in the end. Unfortunately it was not possible to obtain permission for an autopsy.

W. L. Onset of orbital oedema when 4 years old. It was variable in degree Some months later albuminuria was discovered. The patient was admitted to a hospital when $4 \frac{5}{15}$ years old and was diagnosed "chronic nephritis"; treatment included laparotomy for suspected tuberculous peritonitis. Some ascitic fluid was liberated and enlarged mesenteric glands were noted.* When $4_{1:}^{\mathrm{s}}$ years old the patient contracted measles, which caused an exacerbation of oedema.

He was first admitted to hospital at the age of 5 years; and on four subsequent occasions he was re-admitted with exacerbations of nephritis. Edema was generally severe. Several carious teeth were removed. The tonsils were slightly hypertrophied, but were not removed. The urine was always negative for tubercle bacilli: on one occasion a growth of non-hæmolytic streptococci was obtained and the patient received a course of autogenous vaccine. The heart was normal; occasional bronchitis developed. The liver border was palpable $1 \frac{1}{2}$ inches below the subcostal margin in the right nipple line. Its surface was very slightly granular. The eye grounds were normal.

\footnotetext{
* Within the last few weeks I have seen a younger brother of this patient suffering with advanced tuberculous
peritonitis.
} 
The first decapsulation was performed $1 \frac{9}{12}$ years after the onset of symptoms. The left kidney was found to be enlarged and deep red in colour; but it must be remembered that the depth of colour noted at operation is undoubtedly influenced to some extent by traction on the kidney pedicle during the process of bringing the organ into the wound. The kidney capsule was thin and was easily stripped; it was not excised. Perinephric odema was fairly considerable.

At the second operation (right kidney) the findings were similar to those recorded above. There was only slight bulging of the kidney substance when the capsule was incised; and the perinephric tissues were less œedematous than on the left side. A small wedge of kidney substance was removed for histological examination.

During the four months following the second operation there was undoubted improvement in the patient's general condition; œdema diminished to the extent of being a slight puffiness of the face only, the skin colour improved, and the only symptom was some lethargy. Then the former symptonıs returned; œdema increased, and after a fluctuating course the patient died in his own home nine months after operation. It was not possible to perform an autopsy.

M. S. The patient's previous illness was measles, without complications, about two years before the onset of nephritis. This disease began when the child was $55_{1 \frac{7}{2}}^{\frac{71}{2}}$ years old, with gradual swelling of the abdomen and external genitalia. Soon odema of the face, hands and legs developed. Except for occasional slight frontal headache there were no other symptoms of any kind. Clinically there was much œdema, including hydrothorax and ascites. Pyrexia occurred from time to time. The heart was normal. Fourteen carious teeth were removed. The tonsils were slightly hypertrophied; and the eye grounds were normal.

The left kidney was decapsulated 11 months after the onset of symptoms. It was of normal size, with fairly deep sulci, and showed a few pale areas. The capsule stripped easily except at the sulci. Eighteen days after operation his condition showed no odema of the face and only slight puffiness below the knees; skin colour was healthier and the patient much more comfortable. Some bronchitis was present. Table $F$ shows the results of salt excretion tests carried out before, and one montl after, unilateral decapsulation. It is obvious that these tests alone do not demonstrate that the improved power of excreting sodium chloride was due to unilateral decapsulation, but the findings are thought to be of sufficient interest to be recorded.

Decapsulation of the other kidney was deferred on account of recurring and i1 regular pyrexia which lasted about a week. It was decided to allow the patient to return to his own home, on strict diet, for a short period before undergoing the second operation. Unfortunately during this interval he became acutely ill with high fever, very intense œdema, vomiting, diarrhœa and headaches. He did not respond to treatment. On the day before his death, blood culture showed a pure growth of pneumococcus (proved bile-soluble).

Full post-mortem examination was carried out and showed a terminal pneumococcal peritonitis with a slightly turbid effusion. The wall of the left ventricle of the heart was $\frac{3}{8}$ inch thick. The lungs, which were compressed by pleural effusion, showed no rross disease. The spleen weighed $4 \frac{1}{2}$ ounces. The kidneys are described later.

A. S. The patient had suffered no illnesses prior to the onset of orbital oedema, which began at the age of $2 \frac{0}{12}$ years, and alternately disappeared and re-appeared about six times before the patient was admitted to hospital. The only other symptom was oliguria. At no time was blood seen in the urine. Clinically, generalised odema was the most prominent feature. The lieart and lungs were normal. The edge of the liver was palpable one inch below the right subcostal margin in the nipple line; its surface was smooth. The eye grounds were normal, No tubercle bacilli were found in the urine, but a free growth of streptococci was cultured on one occasion. 
TABLE F.

Showing results of salt excretion tests carried out on M. S. (A) before decapsulation, and (B) one month after unilateral decapsulation.

\begin{tabular}{|c|c|c|c|c|c|}
\hline Date. & $\begin{array}{l}\text { Weight in } \\
\text { kilos. }\end{array}$ & $\begin{array}{l}\text { Vol. of urine } \\
\text { in c.cms. }\end{array}$ & $\begin{array}{l}\mathrm{NaCl} \text { percentage } \\
\text { in urine. }\end{array}$ & $\begin{array}{l}\text { Increase in } \\
\mathrm{NaCl} \text { percentage. }\end{array}$ & $\begin{array}{l}\text { Total urinary } \\
\mathrm{NaCl} \text { in gms. }\end{array}$ \\
\hline $12 / 13-3-23$ & $25 \cdot 27$ & - & $0 \cdot 0$ & - & - \\
\hline & \multicolumn{4}{|c|}{10 gms. $\mathrm{NaCl}$ given by mouth on $13-3-23$. } & \\
\hline $13 / 14-3-23$ & $26 \cdot 3$ & 1083 & $0 \cdot 0$ & $0 \cdot 0$ & 00 \\
\hline 14/15-3-23 & - & 1140 & $0 \cdot 06$ & $C \cdot 06$ & $0 \cdot 68$ \\
\hline $15 / 16 / 3 / 23$ & - & 1282 & $0 \cdot 35$ & $0 \cdot 3 \tilde{3}$ & $4 \cdot\{8$ \\
\hline
\end{tabular}

Total urinary $\mathrm{NaCl}$ excretion in 24 hours 0.0 gms.

, , ". ," , 48 ," 0.68 ,

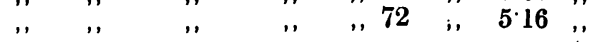

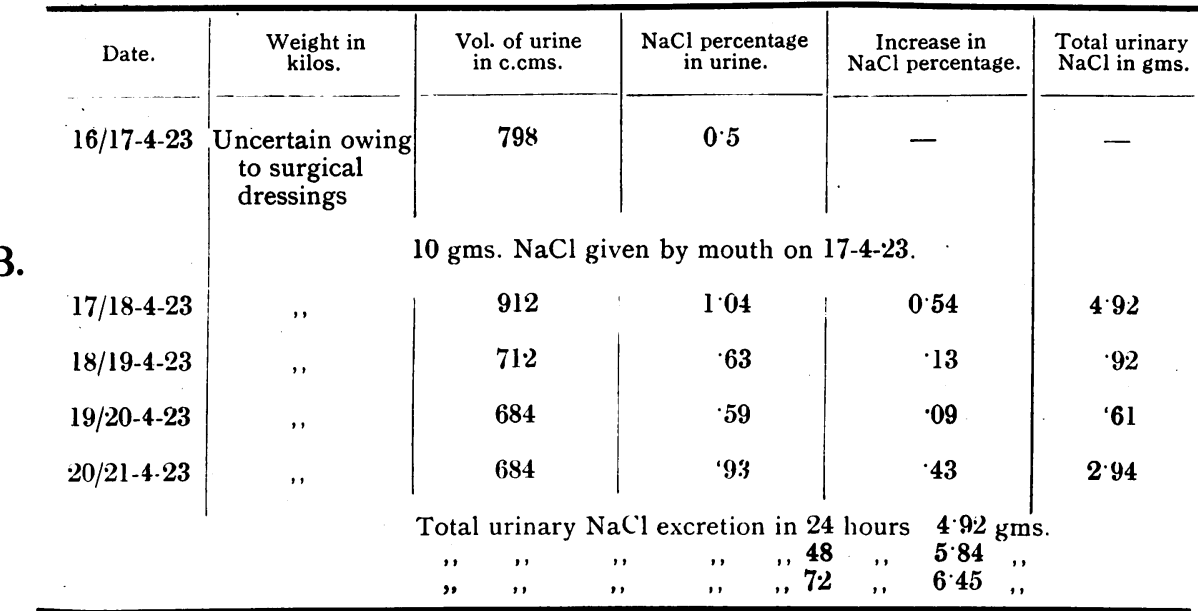

The first decapsulation operation was performed on the right kidney $i^{*}:$ year after the onset of symptoms. The kidney capsule was found to be slightly more adherent than usual to the perinepluric tissues, which were very cedematous. For four days following the operation the child was unusually irritable; obliguria was marked and cedema increased. By the sixth day oedema had consiỏerably diminished again and the ratient's health had improved. There was progressive diminution of dropsy and increased flow of urine.

The left kidney was decapsulated one month after the right. This viscus was found to be remarkably pale: it was larger than the right kidney and its capsule stripped easily. The surrounding tissues were intensely odematous. A small wedge of kidney tissue was removed from each organ for histological examination.

After the second operation there was a temporary exacerbation of symptoms, followed by progressive diminution of cedema, which had disappeared completely two months after the second operation. The patient now looked very pale and wasted, but he was cheerful in spirits. Two months' treatment at a Convalescent Home 
followed; after which the patient returned to his own home, where he has remained for the past two years, with the exception of a short visit to hospital for tonsillectomy and extraction of five carious teeth. It is interesting to note that only slight and temporary odema followed the operation of tonsillectomy under general anæsthesia.

The parents report that the patient's life is now cyclical, with increasing general odema up to a point when diarrhoa, vomiting and polyuria occur. The odema then vanishe:s quickly, leaving the patient very emaciated and hungry. Generally the progressive swelling takes about two months to reach its climax; by the end of the following two to three weeks all oedema has disappeared again. The patient remains in good spirits even when he is œdematous.

The parents are satisfied that since tonsillectomy and dental treatment, the sbove svmptoms have been much less noticeable; and the boy's present condition (Fig. 17) is very satisfactory. He has very slight œdema below the knees; his nutrition is good and his colour is healthy. The heart is of normal size; the blood pressure is higher than normal. No ophthalmoscopic changes can be found. The urine contains 8 gms. of protein per litre; epithelial, granular and hyaline casts are numerous; erythrocytes are absent.

T. W. Both father (Chinese) and mother are healthy. The patient had suffered only one previous illness, when at the age of $2 \frac{4}{12}^{4}$ years she lost consciousness for half an hour. The cause was unknown. From birth there had been continuous oscillatory nystagmoid movements of the right eye.

When $2 \frac{8}{12}$ years old she had " a cold in the head" and was in bed for one week. Three weeks later anorexia, thirst, and swellings around the eyes developed. No change in the urine was at first noticed by the parents. Later diarrhœa, and swellings of the abdomen and ankles, with dysuria and oligurin, developed. The child was then admitted to the Royal Liverpool Children's Hospital. She was drowsy and irritable during examination. The skin was dry and pale. Well-marked generalised odema was present, but there were no signs of effusions into the serous sacs. The heart was of normal size and the first cardiac sound was accentuated at all areas. It was impossible to examine the optic fundi satisfactorily on account of the extreme oedema of the eyelids, and the difficulty of handling the patient. After two months' treatment in hospital, the child develcped rubella and was transferred to a Fever Hospital. She was readmitted at the age of $3 \frac{1^{2}}{2}$ years with an acute exacerbation of nephritis.

The first decapsulation operation (right kidney) was performed five months after the oriset of the primary attack; the viscus was larger and paler than normal and its capsule stripped easily. The left kidney was decapsulated six weeks later; this organ was found to be larger and paler than the right. Its capsule was adherent in one or two places and several small pieces of kidney tissue remained attached to the capsule when this was removed. A small wedge of kidney tissue for microscopical examination was excised from both kidneys.

The patient's condition remained unchanged. Severe general oedema persisted and marked irritability on even the slightest disturbance was a prominent feature. All urine was passed into the bed. These two facts made the case a very unsatisfactory one to follow.

The patient died six weeks after the second operation, and it was not possible to obtain permission for an autopsy.

J. E. The patient's previous illnesses were :--Tonsillitis, at 12 months, whooping cough, at $2 \frac{11}{2}$ years, and occasional mild bronchitic attacks. The present illness developed gradually with slight but variable puffiness around the eyes; this dated from the attack of whooping cough, and had been noted by the parents for several months before the patient was admitted to hospital at the age of $3 \frac{1}{2}$ years. 
NEPHRITIS IN CHILDHOOD

161

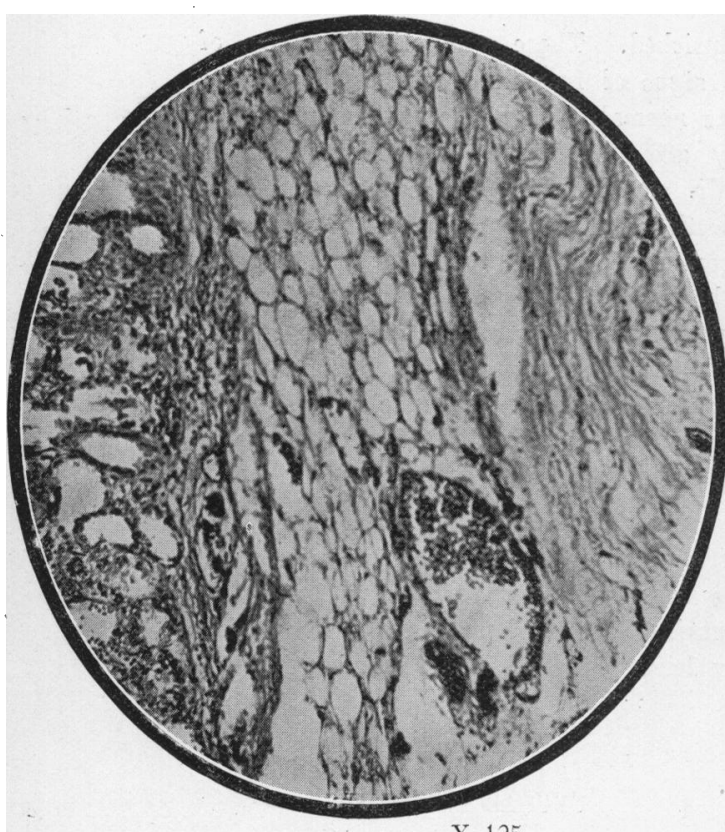

Fig. 15.

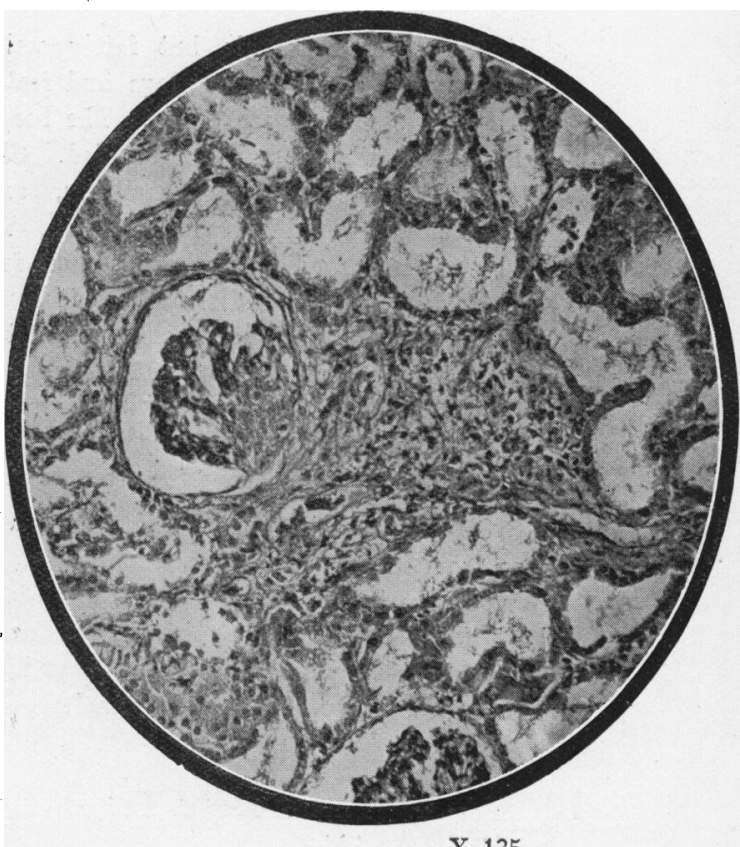

Fing. 16.

X 135 .

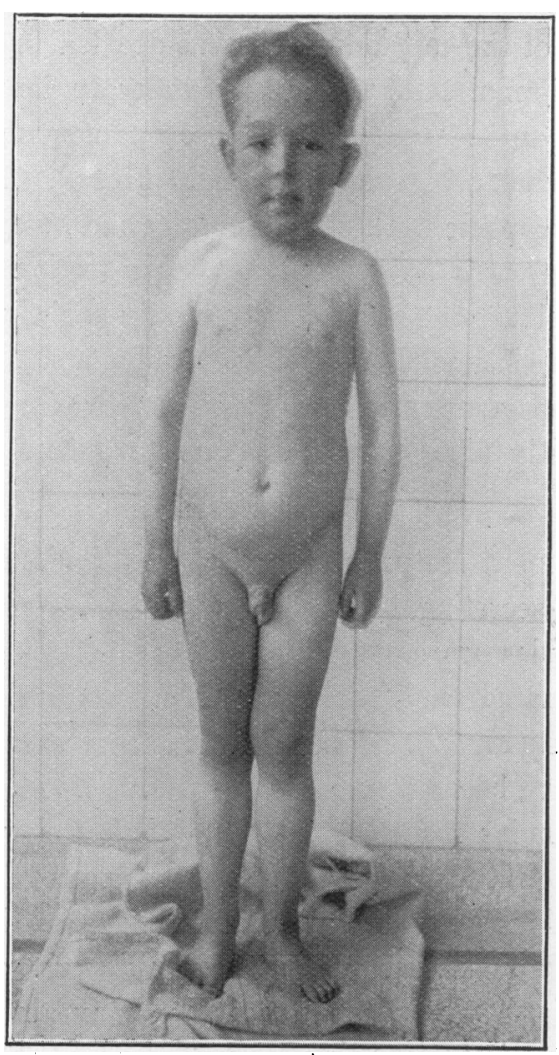

$\frac{7}{3}$
$\frac{1}{3}$
$\frac{0}{0}$

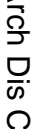

을

$\stackrel{\ddot{\vec{*}}}{\stackrel{9}{0}}$

흠

$\frac{\bar{D}}{\square}$

के

$\overrightarrow{0}$

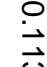

$\vec{\omega}$

응

?

$\vec{\omega}$

$\pm$

의

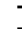

产

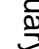

స్

(8)

0
3
0
0
0

잉

을

웅

ำ

$\stackrel{0}{0}$

ำ

I

응

N

స్ట

을

$\stackrel{0}{\stackrel{D}{\Phi}}$

뭉

市

욤

음 
The child was pale but fairly well nourished. There was slight œedema of eyelids, hands and wrists, legs and feet; no signs of free fluid in the pleural or peritoneal cavities were found. The heart was normal. Slight bronchitis was noted and the tonsils were hypertrophied. Shortly after admission the patient had an attack of acute follicular tonsillitis, and Mr. P. W. Leathart considered that tonsillectomy would be required later. The teeth were sound. The patient improved and was discharged to his home almost free from odema. He continued to attend the Out-Patient Department of the lospital. At the age of $3 \frac{9}{12}$ years he passed through reasles and broncho-pneumonia without any recurrence of vedema or other special kidney signs. In September, 1924 (age 5 years), the patient was in bed for five weeks with right-sided pleuro-pneumonia; again no special kidney signs were noted. With the exception of these illnesses the boy has enjoyed very good health. There have been no swellings or headaches; the sight is goorl and the optic fundi are normal.

Clinical examination at the present time shows the patient to be well nourished, free from odema and of healthy colour. Several teeth which recently became carious have received attention. The systolic blood pressure is $115 \mathrm{~mm}$. of mercury, which is ligh for a child of $5 \frac{\mathrm{s}}{12}$ years. The urine contains $8 \mathrm{gms}$. of protein per litre, with granular and hyalo-granular casts, and a few leucocytes and large round epithelial cells. No erythrocytes can be found.

\section{Pathological findings in J)iffuse Tubular Nephritis.}

Reference has already been made to the naked eye appearance of the kidneys at operation. At the autopsy performed upon M. S., who died 86 days after decapsulation of the left kidney, it was decided to remove this kidney intact with its peri-renal fatty tissues, in order to investigate histological changes resulting upon decapsulation. These findings are noted below. The right kidney was found to be enlarged (weight 5 ozs.). The capsular vessels. were congested; the capsule itself stripped easily and no cysts were seen. The surface of the kidney was not granular. Cross section showed the cortex to be very pale in colour; the pyramids were only slightly paler than normal. 'I'here were no visible hæmorrhages. The bladder and ureters were normal. The histological appearances of the kidney wedges removed in different cases were sufficiently alike to permit a single general description of the sondition.

The most prominent feature noted is advanced granular degeneration of the cells lining the secreting tubules (Fig. 1), which are dilated. Most of these expanded tubules are empty, but in some portions the secreting cells have been desquamated and the tubules are partially filled with their degenerated remains (Fig. 2). There are scattered areas of necrosis where groups of tubules have become entirely disintegrated. Many of the collecting tubules contain granular masses (casts) and their lining cells show cloudy swelling. The glomeruli show several different types of pathological change, in varying grades. Some are swollen and congested as the result of cellular infiltration with mononuclears and, to a lesser degree, with polymorphonuclear leucocytes (Figs. 2, 10); the glomerulus may almost fill the capsule of Bowman (Fig. 2). Occasionally a hyaline thrombus is visible within the tuft (Fig. 3). Exudation into the capsule of Bowman is frequently noted; 
most often it resembles " streamers" passing between the tuft and the inner surface of the capsule (Figs. 1, 4). Some glomeruli show a further stage of the same process, with adhesion to the capsule (Fig. 6) and the formation of epithelial crescents (Figs. 7, 7a). The capsule may be lined by a thin hyaline deposit (Fig. 3); in some cases this is laminated (Figs. 5, 5a).

The most advanced stage of degeneration appears to consist of fibroblastic infiltration of glomeruli which have undergone some or all of the changes described above; the remnants of these tufts can be seen as semiselerotic masses (Figs. 5, 5a, 8, 9, 16). The fact that in places the glomeruli appear to be in closer juxtaposition than usual may point to shrinkage of the kidney. The connective tissue shows areas of infiltration with small round cells; fibroblasts, polymorphs and erythrocytes are less numerous (Figs. 5, 5a, 7, 7a, 9, 11, 16). These areas form more or less circumscribed zones, and the adjacent epithelial cells show advanced degrees of the changes previously noted. Newly-formed fibrous tissue may be seen scattered in sheaf-formation (Fig. 12); probably it is not yet contracting, because the tubules lying between its strands do not appear to be compressed.

The only pathological change noted in the portions of kidney capsule removed with the wedges of renal tissue was some slight thickening in patches. The larger blood vessels of the kidney showed no pathological changes. The kidneys removed from M. S. at autopsy demand special notes. The left kidney, which had been decapsulated three months previously, was hardened in its bed of surrounding fat and sections were examined microscopically (Figs. 13, 14, 15, 16). With the exception of thin fibrous strands (see Fig. 13) there is no newly-formed capsule. The peri-renal fat contains numerous blood vessels, but careful search did not demonstrate that any of these passed into the kidney substance. Comparison of these sections with the illustration of a case examined by Dr. John H. Larkin for Dr. Edebohls(7) shows most striking differences. In the latter case four months had elapsed between decapsulation and the death of the patient. It would seem unlikely that the new vascular capsule which Larkin figures could have developed in the extra month of life which the patient enjoyed, in comparison with my patient. Furthermore, it should be noted that the patient of Edebohls was an adult, and therefore less likely than a child of $6 \frac{1}{2}$ years to show reparative changes in her kidneys.

\section{Treatment.}

I do not propose to deal with all the well-recognised and accepted methods of treatment of nephritis. I shall draw attention to the following points only:-

(1) In diffuse tubular nephritis the diet should be rich in protein and should have a high calorie content. 
(2) As diuretics for œłlematous patients, alkalis and urea by mouth are undoubtedly of value. Calcium lactate has been advocated by Boyd(2) and calcium chloride by Keith, Barrier and Whelan(15). I have used the former without success.

(3) The removal of septic foci, e.g., teeth, tonsils, sinus disease, is of great importance in the treatment of the present attack and as a safeguard against recurrences.

(4) Parents must be warned of the possibility and danger of slight exacerbations, and must guard the child against chills, intestinal disturbances and mild infections generally. Too much emphasis cannot be placed upon the comparative mildness of the general symptoms which to the parent may be the only signs of progressive kidney disease.

(5) Decapsulation of the kidneys was followed by some temporary improvement in my cases; and one child (A. S.) has undoubtedly derived great benefit.

\section{Summary and Conclusions.}

1. I have suggested what appears to me to be a suitable clinical and pathological classification for the inflammatory kidney diseases of childhood.

2. I have reported my findings in a small group of cases.

3. On these findings I would say that:-

(a) Renal efficiency tests, while certainly to be commended on general principles as the rational procedure in investigation of disease, have not in my. experience furnished any diagnostic information of importance [see Crawford(5)]. On the other hand they are sometimes of help in determining the degree of the lesion, and whether it is. advancing or retrogressing. They are of most value in prognosis and in directing diet and treatment. The tests must be repeated and taken into consideration along with clinical and other laboratory findings.

It can be stated definitely that continued nitrogen retention is of importance and denotes serious damage; and that a persistently low 'phthalein excretion is also serious.

(b) Kidney decapsulation is worthy of further trial. It is probable that results would be better if the operation were carried out sooner.

My best thanks are tendered to the Medical Research Council for enabling me to carry out these investigations, and for defraying the laboratory expenses. With one exception the patients were studied in Dr. Dingwall Fordyce's ward at the Royal Liverpool Children's Hospital, and I am greatly indebted to him for his helpful advice. Dr. J. Murray 13ligh kindly allowed me to study one of his cases (M. S.). I gladly acknowledge 
the help which the following gentlemen have given in their own special departments: Mr. R. C. Dun, Professor E. E. Glynn, Mr. 'Thurstan Holland, Mr. F. A. G. Jeans, Dr. Howell Evans, Dr. P. W. Leathart, and Mr. P. G. Capons. The microscopical sections were prepared in Professor Glynn's laboratory.

\section{REFERENCES.}

1. Āllison, R. S. : Practilioner, 1925, cxiv, 222.

2. Boyd, G. : $\Lambda m$. Jnl. Dis. Children, Chicago, 1922, xxiii, 375

3, Cautley, E.: Arch. of Pediatrics, N.Y., 1923, xl, 84.

4. Clausen, S. W. : Am. Jnl. Dis. Children, Chicago, 1925, xxix, 581 .

5. Crawford, E. : Glasgow Med. Jnl., 1924, ci, 72.

6. Curtis, R. D. : Abt's Pediatrics, Vol. IV, Chapter xcvi, Philadelphia, 1924.

7: Edebohls, G. M.: “ The Surgical Treatment of Bright's Disease," New York, 1904.

8. Emerson, C. P.: Jnl. Am. Med. Assoc., Chicago, 1921, lxxvii, 745.

9. Epstein, A. A. : Am. Jnl. Med. Sci., Philadelphia, 1917, cliv, 638.

10. Fordyce, A. D., and Capon, N. B. : Brit. Jnl. Child. Dis., 1924, xxi, 1.

11. Gittings, J. C., and Mitchell, A. Græme : Am. Jnl. Dis. Children, Chicago, 1917, xiv, 174 .

12. Heubner, O.: "Uber chronische Nephritis und Albuminurie im Kindesalter," Berlin, 1897.

13. - _Lehrbuch der Kinderheilkunde," Vol. ii, Leipzig, 1911.

14. Hill, L. W. : Am. Jnl. Dis. Children, Chicago, 1917, xiv, 267.

15. Keith, N. M., Barrier, C. W., and Whelan, M. : Jnl. Am. Med. Assoc., Chicago, 1924, Ixxxiii, 666.

16. Leopold, J. S., and Bernhard, A. : .4m. Jnl. Dis. Children, Chicago, 1916, xi, 432.

17. Linder, G. C., Lundsgaard, C., and van Slyke, D. D., Jnl. Es:p. Med., N.Y., 1924, xxxix, 887.

18. McLean, H.: "Modern Methods in the Diagnosis and Treatment of Renal Disease," London, 1924.

19. MeNee, J. W. : Jnl. Path. and Bact., Edin., 1925, xxxvi, 260.

20. Major R. H., and Helwig, F. C.: Bull. J. Hopkins Hosp., Baltimore 1925, xxxvi, 260 .

21. Marriott, W. M. : Med Clinics N. Am., Philadelphià, 1924, vii, 1413.

22. Medical Science, 1920, ii, 50 .

23. Mendel, L. : Monatschr. f. Kinderheilk., Leipzig, 1923, xxvii, 27.

24. Morse, J. Lovett: Jnl. Am. Med. Assoc., Chicago, 1917, lxix, 525.

25. Munk, F.: "Pathologie und Klinik der Nephrosen, Nephritiden und Schrumpfnieren," Berlin, 1918.

26. Myers, V. C. : “Practical Chemical Analysis of Blood," London, 1921.

27. Newburgh, L. H: : Medicine, Baltimore, 1923, ii, 77.

28. Schwartz, H., and Kohn, J. L. : Am. Jnl. Dis. Children, Clicago, 1922, xxiv, 125.

29. Smith, D. L., and Bailey, C. W. : Arch. of Pediatrics, N.Y., 1923, xl, 525.

30. Tileston, W., and Comfort, C. : Am. Jnl. Dis. Children, Chicago, 1915, x, 278.

31. Tripputi, V.: La Pediatria, Naples, 1924, xxxii, 482.

32. Volhard, F., and Fahr, T. : "Die Brightische Nierenkrankheit," Berlin, 1914.

33. Wilcox, H. B., and Lyttle, J. D. : Am. Jnl. Dis. Children, Chicago, 1923, xxvi, 195. 